\title{
The Effect of Glandless Cottonseed Meal Content and Process Parameters on the Functional Properties of Snacks during Extrusion Cooking
}

\author{
Damian Reyes-Jáquez ${ }^{1}$, Favio Casillas ${ }^{2}$, Nancy Flores ${ }^{2}$, Isaac Andrade-González ${ }^{3}$, Aquiles Solís-Soto ${ }^{1}$, \\ Hiram Medrano-Roldán ${ }^{1}$, Francisco Carrete $^{4}$, Efren Delgado ${ }^{{ }^{*}}$ \\ ${ }^{1}$ Graduate School of Biochemical Engineering, Technological Institute of Durango, Durango, México; ${ }^{2}$ Extension Food Technology, \\ New Mexico State University, Las Cruces, USA; ${ }^{3}$ Technological Institute of Tlajomulco, lajomulco de Zúñiga, México; ${ }^{4}$ Faculty of \\ Veterinary, Juarez State University of Durango, Durango, México. \\ Email: edelgad@itdposgrado-bioquimica.com.mx
}

Received October $2^{\text {nd }}, 2012$, revised November $9^{\text {th }}, 2012$; accepted November $16^{\text {th }}, 2012$

\begin{abstract}
The results of the present study indicate that glandless cottonseed meal (CSM) can be incorporated in extruded corn flour snacks at a $10 \%$ content level, which increases snack protein content to $12.8 \%$ and reduce fat content to $6.2 \%$. To improve snacks' nutritional quality, CSM and corn flour were extruded using a simple screw extruder. An expansion index (EI) ranging of 1.2 - 4.7 was obtained. Penetration force (PF) was 7 - 9 times harder than other extruded products. High extrusion temperature and high CSM concentrations decreased $(p<0.05)$ EI, water activity, and water absorption index. Higher CSM concentrations can be incorporated into extrudates if snacks are processed at higher extrusion moistures. CSM increased $(p<0.05)$ extrudates' PF giving them a unique crunchy texture. CSM decreased $(p<0.05)$ extrudates' water solubility index. Extrusion conditions used showed a $68.5 \%$ starch gelatinization, and a starch availability of more than $97 \%$, which explains the high expansion index obtained.
\end{abstract}

Keywords: Cottonseed Meal; Extruded Snack; Functional Properties

\section{Introduction}

It is generally accepted today that, in order to adequately feed the world's rapidly expanding population, increasing amounts of plant proteins should be directly used in human diets. A feasible option is to use protein obtained from the cotton plant. Cotton should rank high among crop production priorities since it provides fiber, a renewable resource for garment manufacturing, as well as edible oil and protein for human consumption and animal feed [1]. However, it contains gossypol, a natural phenollic aldehyde that permeates cells and acts as an inhibitor for several dehydrogenase enzymes [2], it can cause negative effects on growth and reproductive performance, and it can also result in intestinal and internal organ abnormalities [3-5]. Glandless cottonseed flour could potentially be used as raw material for the production of texturized protein products. This is achieved by genetically eliminating the toxic compound gossypol from the cottonseed [6]. Cottonseed meal (CSM) is obtained by grinding the flakes once most of the cottonseed oil has been removed.

${ }^{*}$ Corresponding author.
Hominy is obtained through a process called nixtamalization, which is a traditional alkali treatment in which corn is precooked with $\mathrm{Ca}(\mathrm{OH})_{2}$, conditioned for $6-18 \mathrm{~h}$, and ground to produce corn flour (Gomez et al., 1991). Tortilla and other corn products are made from corn flour [7-10]. During nixtamalization, partial starch gelatinization and retrogradation take place, while starch birefringence decreases [8-12]. Nixtamalization increases Lys/Iso ratio, $\mathrm{Ca}$ content, and protein digestibility and decreases aflatoxin contamination [13-17].

Extrusion is inexpensive, productive and requires low levels of energy [18]. Snacks can be extruded products [17]. Because starch gelatinization provides texture and structure to the end-product $[19,20]$, it is possible to produce extrudates from pure starch or high starch content cereals. Because of cottonseed meal's relatively high protein and fat content and its low starch content, extrusion of cottonseed meal is complicated. Other results show that high protein legumes can be extruded, obtaining an expansion index ranging between 1.5 and 2 at $18 \%$ of moisture [21]. Expansion, in general, increases with higher extrusion moisture, pressure and temperature [22]. 
Although the use of corn flour and bean flour showed that expansion index, apparent density, water solubility index, water absorption index and initial viscosity were significantly $(p<0.05)$ higher when bean-corn flour was extruded at high temperature and low moisture conditions, the best extrusion conditions were obtained at $190^{\circ} \mathrm{C}$ and $14.5 \%$ moisture [17]. Bulk density can be increased by decreasing moisture content, barrel temperature and screw speed. The expansion and texture of extrudates is more complex for products made with more than one component [17,23-25]. The multiphase structure affects the elastic properties of extrudates. Expansion is reduced at concentrations of $50 \%$ of each component. It has been demonstrated that plant protein can be combined with corn flour protein as a complement to obtain highly valuable protein flour, and that extrusion is an alternative processing method for obtaining extruded products with high protein content for human or animal consumption [2325]. Extruded snacks are quite popular [26]. An extruded snack made of cottonseed meal-corn flour may increase its nutritional value. The aim of this study was to evaluate the effect of extrusion temperature, screw speed, cottonseed meal and moisture content on the functional properties of a snack made from glandless cottonseed meal.

\section{Materials and Methods}

\subsection{Cottonseed Meal (CSM) and Corn Flour (M)}

According to the experimental design, a set of 27 treatments was elaborated with $1.5 \%$ of chili flour, $0.5 \%$ of salt and different cottonseed meal/corn flour (CSM/M) proportions $(5 / 93,10 / 88,1583,20 / 78$ and 25/73). The ingredients used were: glandless cottonseed meal (CSM) (\#2812-1, provided by Cotton Incorporated ${ }^{\mathbb{B}}$ ), white corn flour (M) $\left(\right.$ Maseca $\left.^{\circledR}\right)$, green chili flour (Capsicum annuum) and salt (Shur fine Iodized salt ${ }^{\circledR}$ ). All ingredients were milled to less than $2 \mathrm{~mm}$ diameter.

\subsection{Chemical Composition}

Proximate chemical compositions of the optimal treatment as well as two commercial corn-based snacks were determined in triplicate according to AOAC methods [27]. Crude fiber was measured by acid-alkaline digestion [28]. Nitrogen free extract (NFE) was calculated as the percentage difference of the sum of protein, fiber, fat and ash content.

\subsection{Mycotoxins Analysis}

Aflatoxins B1, B2, G1 and G2A were analyzed in corn flour and cottonseed meal following Xinlei's method [29].

\subsection{Starch Analyses}

Starch gelatinization, total starch and available starch were measured according to AOAC Method 979.10 [27].

\subsection{Extrusion}

Treatments were conducted as follows: a Brabender laboratory simple-screw extruder (Model 2003, C. W., Disburg, Germany) was used with the following characteristics: three heating zones $\left(100,110^{\circ} \mathrm{C}\right.$ for the first and second zone respectively, and the third one was adjusted according to the experimental design), screw compression force 3:1, longitude/diameter ratio (L/D) 20:1, screw diameter of $19 \mathrm{~mm}$ and an exit die with a $3 \mathrm{~mm}$ internal diameter.

Before extrusion, a formulate mixture was prepared and humidity content was adjusted from $12 \%$ to $20 \%$ following the experimental design. Screw speed and temperature in the third extrusion zone were varied as shown in Table 1. Desired moisture level was adjusted by spraying distilled water onto the mix of ingredients, which was then hand mixed for $15 \mathrm{~min}$ and conditioned for $12 \mathrm{~h}$ in closed plastic containers at $4^{\circ} \mathrm{C}$. Three separate extrusion runs were carried out for each sample. The extruded samples were dried in a convection oven at $80^{\circ} \mathrm{C}$ for $1 \mathrm{~h}$, chilled at room temperature for $1 \mathrm{~h}$, and stored in sealed polyurethane bags at $4^{\circ} \mathrm{C}$ for later analysis.

\subsection{Experimental Design and Data Analysis}

A central composite design with four independent variables was performed. The independent variables considered were temperature at the exit of the die $\left(X_{1}\right)$, screw speed $\left(X_{2}\right)$, moisture content $\left(X_{3}\right)$, and CSM content $\left(X_{4}\right)$ (Table 1). The response variables were expansion index (EI), water activity (WA), penetration force (PF), water absorption index (WAI), water solubility index (WSI), and bulk density (BD). The design was developed and analyzed using commercial software (Design-Expert 7.0.0 ${ }^{\circledR}$, State-Ease Inc., Minneapolis, MN, U.S.A.). Results were analyzed by multiple quadratic regressions (Equation (1)). Experimental data was adjusted to selected models and regression coefficients were obtained.

Table 1. Coded levels of four independent variables.

\begin{tabular}{cccccc}
\hline \multirow{2}{*}{ Factor } & \multicolumn{5}{c}{ Variation Levels } \\
\cline { 2 - 6 } & $-\boldsymbol{\alpha}$ & $\mathbf{- 1}$ & $\mathbf{0}$ & $\mathbf{+ 1}$ & $+\boldsymbol{\alpha}$ \\
\hline Temperature $\left({ }^{\circ} \mathrm{C}\right)$ & 105 & 120 & 135 & 150 & 165 \\
Screw speed $(\mathrm{RPM})$ & 90 & 120 & 150 & 180 & 210 \\
Moisture $(\%)$ & 12 & 14 & 16 & 18 & 20 \\
CSM content $(\%)$ & 5 & 10 & 15 & 20 & 25 \\
\hline
\end{tabular}

$(\alpha=2)$. 
Statistical significances of the regressions terms were examined by variance analyzes (ANOVA) for each response.

$$
\begin{aligned}
y & =B_{0}+B_{1} X_{1}+B_{2} X_{2}+B_{3} X_{3} \\
& +B_{4} X_{4}+B_{11} X_{1}^{2}+B_{22} X_{2}^{2} \\
& +B_{33} X_{3}^{2}+B_{44} X_{4}^{2}+B_{12} X_{1} X_{2} \\
& +B_{13} X_{1} X_{3}+B_{14} X_{1} X_{4}+B_{23} X_{2} X_{3} \\
& +B_{24} X_{2} X_{4}+B_{34} X_{3} X_{4}
\end{aligned}
$$

\subsection{Process Optimization}

Numerical optimization was performed for response variables (WAI, WSI, WA, PF, BD and EI), as well as surface superposition for each treatment. Commercial snacks were used to determine the intervals for EI (1.40 to 1.81), BD $\left(258-671 \mathrm{~kg} / \mathrm{m}^{3}\right)$, WAI (4.17 to $\left.4.39 \mathrm{~g} / \mathrm{g}\right)$, WSI ( $8.14 \%$ to $11.45 \%$ ), WA (0.09 to 0.15$)$ and PF (18.01 to $20.17 \mathrm{~N}$ ) in the surface superposition.

\subsection{Expansion Index (EI) and Bulk Density (BD)}

EI was measured by dividing the diameter of the extruded product by the diameter of the socket opening in the extrusion exit [30]. BD was determined as described above [31]. Diameter $(d)$ and longitude $(l)$ were measured for 10 randomly selected samples. Three diameter measurements were taken from each sample and the average value was calculated. Then each extrudate was weighed $(\mathrm{Pm})$ to calculate density by using Equation (2) (the results were expressed in $\mathrm{Kg} / \mathrm{m}^{3}$ ):

$$
\text { Density }=\frac{P m}{\pi\left(\frac{d}{2}\right)^{2} l}
$$

\subsection{Penetration Force (PF)}

This is a textural variable evaluated using a texture profile analysis with the TA-XT2j (Texture Technologies Corp., Scarsdale, NY/Stable MicroSystems, Haslemere, Surrey, UK). Penetration force was measured by shearing 20 samples from each trial using a Warner Brazler blade probe with a sensitivity of $1 \mathrm{~kg} /$ force and $2 \mathrm{~cm} \cdot \mathrm{min}^{-1}$ [17].

\subsection{Water Activity (WA)}

WA was measured using an AQUALAB 4 TE (Decagon Devices). Each sample was measured by duplicate with an accuracy of \pm 0.003 .

\subsection{Water Absorption Index (WAI) and Water Solubility Index (WSI)}

The water absorption index (WAI) and water solubility index WSI) were determined as outlined before [32].

\section{Results and Discussion}

\subsection{Chemical Composition}

Fat, protein, fiber, ash, and nitrogen free extract (NFE) of CSM, CSM/corn flour extrudate and commercial snacks are summarized in Table 2. Fat and protein content in CSM is higher than in legumes or corn used for extrusion by other authors $[23,24]$, while the NFE is lower. Low NFE concentrations limit significantly the amount of CSM used for extrusion. Protein and starch content in $\mathrm{CSM} /$ corn flour extrudate is higher, while fat is lower than commercial extrudates. Our results are consistent with other studies where a higher protein content was shown when using composite flours and/or agro-industrial residues for extrusion than when only corn is used [33-35]. Mixing CSM and corn flour can significantly ( $p$ $<0.05$ ) increase dietary protein and lower fat content in snacks as shown in this work and other findings, whereas composite flours can improve the nutritional value of food [36-39].

\subsection{Expansion Index (EI)}

Moisture content increased $(p<0.05)$ EI. The interaction with higher screw speed and higher CSM concentrations also resulted in a higher EI (Table 3). These results agree with findings in soybean flour and high starch content extrudates $[40,41]$. High moisture content increases pressure in the extruder, causing the product to expand at the die, due largely to flashing water vapor caused by abrupt pressure changes [42-45]. High extrusion temperature and high temperatures combined with high screw speed reduced $(p<0.05)$ EI of extrudates, in contrast to other studies [46], where extrusion of bean flour alone had a lower $\mathrm{EI}$ at $140^{\circ} \mathrm{C}$ than at $180^{\circ} \mathrm{C}$. At high temperatures, starch may dextrinize reducing EI, especially with low starch content mixtures [47-51].

The results also showed that an increase on CSM decreases $(p<0.05)$ EI, unless moisture content is increased. Lowest EI obtained when CSM content is increased may be due to differences in internal structures of extrudates. It has been demonstrated that there exists a structural relationship between protein and starch tractions in extrudates. CSM extrudates are composed of a protein matrix with different uniformity, in addition to insoluble carbohydrates which are dispersed. Extrudates with high protein content have small cells with wrinkled walls $[52,53]$. This explains why our CSM extrudates are crunchy, while other extruded products are smooth and have continuous structures. Crunchiness in CSM extrudates is the result of differences in internal extrudate 
Table 2. Chemical composition of commercial snacks and $10 \%$ cottonseed meal/corn flour extrudates (g/100g DM).

\begin{tabular}{ccccccc}
\hline Sample & Crude Fat & Crude Protein & Crude Fiber & Ash & NFE & Mycotoxins $^{*}$ \\
\hline Corn Flour & - & - & - & - & - & n.d \\
CSM & 12.6 & 55.3 & 1.0 & 7.83 & $8.2^{1}$ & n.d \\
Extrudates & 6.2 & 12.8 & 1.7 & 2.23 & 77.07 & - \\
Commercial Snack-1 & 26.4 & 7.2 & 2.7 & 4.61 & 59.09 & - \\
Commercial Snack -2 & 32.0 & 6.4 & 1.5 & 2.75 & 57.35 & - \\
\hline
\end{tabular}

NFE = Nitrogen free extract; ${ }^{1}$ determined as non-fiber carbohydrate; - = not determined; n.d. = not detected; Aflatoxin B1, B2, G1, G2 (ppb), vomitoxin (ppm), 3-Acetyl.

Table 3. Regression coefficients models (coded factors) of extruded diets.

\begin{tabular}{|c|c|c|c|c|c|c|c|c|c|c|c|c|c|c|c|c|}
\hline \multirow{3}{*}{ Response } & \multicolumn{15}{|c|}{ Coefficients } & \multirow{3}{*}{$R^{2}$} \\
\hline & \multirow{2}{*}{$\begin{array}{c}\text { Intercept } \\
b_{0}\end{array}$} & \multicolumn{4}{|c|}{ Lineal } & \multicolumn{4}{|c|}{ Quadratics } & \multicolumn{6}{|c|}{ Interactions } & \\
\hline & & $X_{1}$ & $X_{2}$ & $X_{3}$ & $X_{4}$ & $X_{1}^{2}$ & $X_{2}^{2}$ & $X_{3}^{2}$ & $X_{4}^{2}$ & $X_{1} X_{2}$ & $X_{1} X_{3}$ & $X_{1} X_{4}$ & $X_{2} X_{3}$ & $X_{2} X_{4}$ & $X_{3} X_{4}$ & \\
\hline EI & $2.81^{*}$ & $-0.31^{*}$ & 0.022 & $0.37^{*}$ & $-0.78^{*}$ & -0.084 & 0.1 & -0.19 & 0.013 & $-0.3^{*}$ & 0.053 & 0.015 & $0.31^{*}$ & 0.006 & $0.27^{*}$ & 0.75 \\
\hline $\mathrm{PF}$ & $34.83^{*}$ & -1.88 & $-3.9^{*}$ & $-6.81^{*}$ & $6.34^{*}$ & $-4.0^{*}$ & -2.26 & 2.69 & -0.95 & $5.14^{*}$ & -0.97 & -3.9 & -3.46 & -0.81 & $-6.84^{*}$ & 0.62 \\
\hline $\mathrm{BD}$ & $456.63^{*}$ & 40.75 & 23.54 & $-184.9^{*}$ & $198.1^{*}$ & -27.61 & -60.41 & 50.36 & 30.92 & $95.37^{*}$ & -3.82 & -48.34 & $-81.43^{*}$ & -20.6 & $-112.8^{*}$ & 0.73 \\
\hline WA & $0.24^{*}$ & $-0.03^{*}$ & $-0.021^{*}$ & $0.029^{*}$ & $-0.03^{*}$ & $-0.02^{*}$ & $-9.6 \mathrm{E}-4$ & -0.006 & $5.0 \mathrm{E}-5$ & 0.023 & $-0.034^{*}$ & 0.006 & -0.012 & 0.019 & -0.003 & 0.57 \\
\hline WAI & $4.56^{*}$ & 0.048 & 0.057 & $0.52^{*}$ & $-0.54^{*}$ & 0.13 & 0.12 & -0.026 & -0.047 & -0.17 & 0.037 & $0.25^{*}$ & $0.26^{*}$ & 0.025 & $0.25^{*}$ & 0.78 \\
\hline WSI & $14.08^{*}$ & $-1.19^{*}$ & -0.28 & 0.85 & $-1.05^{*}$ & 0.17 & $1.05^{*}$ & -0.69 & -0.29 & $-1.64^{*}$ & -0.094 & 0.13 & $1.25^{*}$ & -0.12 & $1.82^{*}$ & 0.59 \\
\hline
\end{tabular}

$X_{1}=$ Temperature; $X_{2}=$ Screw speed $X_{3}=$ Moisture content; $X_{4}=$ Cottonseed meal content. ${ }^{*}$ indicate significant difference $(p<0.05)$. EI $=$ Expansion index, PF

$=$ Penetration force, $\mathrm{BD}=$ Bulk density, WA $=$ Water activity, WAI = Water activity index, WSI = Water solubility index.

structure [17]. CSM has high protein content (Table 2), which results in low EI. We have shown in earlier works that extrusion of high protein composite flours of beancorn flour can be successfully achieved with EI ranging from 1.6 - 1.8 [17]. Results for this test show an EI ranging from 1.2 - 4.7 (Table 4). Samples with only 5\% CSM have the highest EI. Other results show extruded CSM with EI ranging from 1.1 - 1.5 [40,54]. Other authors also obtained similar EI with corn or wheat flour complemented with bean proteins or soybean flour, respectively $[53,54]$. Changes in extrudate functional properties such as EI are due to structural starch transformations [55-57].

\subsection{Penetration Force (PF)}

PF or hardness was affected $(p<0.05)$ by extrusion moisture and CSM concentration (Table 3). Snacks extruded at higher moisture content were softer $(p<0.05)$ than snacks extruded at lower moisture. Other authors also found an effect of moisture on texture properties of soybean and wheat flour blends [58]. Extrudates with high CSM concentrations were harder than extrudates with small amounts of CSM. Hardness increased $(p<$ 0.05 ) when temperature and screw speed increased, yet it decreased when CSM concentration and moisture were simultaneously increased while holding all other variables constant. Compared to bean/corn flour extrudates [17], CSM/corn flour extrudates are 7 - 9 times harder
(Table 4). PF represents physical and chemical properties of the extrudate. It is strongly related to raw material makeup such as starch content and extrusion parameters, including temperature and moisture [59].

\subsection{Bulk Density (BD)}

$\mathrm{BD}$ for extruded treatments is directly related to expansion occurring during extrusion [60]. In addition, it is generally affected by particle size and it plays a decisive role in package design and product handling [61]. In keeping with other findings [60,62], BD was not influenced $(p<0.05)$ by temperature (Table 3). BD decreased $(p<0.05)$ with increasing moisture content while it increased with higher CSM content and when temperature and screw speed were increased simultaneously. Increasing either screw speed and moisture or moisture and CSM concentration at the same time resulted in lower $(p<0.05) \mathrm{BD}$ values. A lower BD indicates a better extrudate structure and a higher EI [53]. The obtained bulk density is comparable to the obtained by other authors in bean/corn flour extrudates [17]. Protein-enriched extrudates have a BD of up to $600 \mathrm{Kg} / \mathrm{m}^{3}$ [53]. Nevertheless, some extruded CSM/corn flour samples in this study had higher values (Table 4), indicating a rougher structure of extrudates and hence, a crunchier product. Other authors have also reported that protein type and concentration influence $\mathrm{EI}$ and $\mathrm{BD}$ [63]. A BD decrease 
Table 4. Functional and physical properties of CSM-masa extrudates produces at different extrusion temperature, screw speed, moisture and CSM content.

\begin{tabular}{|c|c|c|c|c|c|c|c|}
\hline $\mathrm{T} / \mathrm{rpm} / \mathrm{EM}$ & $\operatorname{CSM}(\%)$ & EI & $\mathrm{PF}(\mathrm{N})$ & $\mathrm{BD}\left(\mathrm{kg} / \mathrm{m}^{3}\right)$ & Water activity & WAI (g/g) & WSI (\%) \\
\hline $135 / 150 / 16$ & 5 & $4.64 \pm 0.365^{*}$ & $16.45 \pm 5.201$ & $95.12 \pm 24.069$ & $0.34 \pm 0.024$ & $5.67 \pm 0.671$ & $15.34 \pm 2.163$ \\
\hline $150 / 120 / 18$ & 10 & $3.29 \pm 0.284$ & $18.64 \pm 4.422$ & $170.63 \pm 27.233$ & $0.15 \pm 0.020$ & $5.18 \pm 0.014$ & $15.74 \pm 3.911$ \\
\hline $150 / 180 / 14$ & 10 & $1.23 \pm 0.027$ & $45.44 \pm 20.785$ & $972.50 \pm 37.849$ & $0.10 \pm 0.013$ & $3.55 \pm 0.084$ & $9.43 \pm 2.441$ \\
\hline $120 / 180 / 18$ & 10 & $4.09 \pm 0.259$ & $12.42 \pm 4.192$ & $131.32 \pm 19.949$ & $0.19 \pm 0.010$ & $5.85 \pm 0.149$ & $17.90 \pm 0.362$ \\
\hline $120 / 120 / 18$ & 10 & $2.56 \pm 0.106$ & $52.85 \pm 33.406$ & $399.80 \pm 50.861$ & $0.46 \pm 0.033$ & $5.25 \pm 0.486$ & $10.43 \pm 2.932$ \\
\hline $150 / 180 / 18$ & 10 & $3.81 \pm 0.324$ & $16.17 \pm 5.066$ & $136.25 \pm 28.379$ & $0.21 \pm \quad 0.022$ & $5.58 \pm 0.276$ & $13.87 \pm 1.931$ \\
\hline $150 / 120 / 14$ & 10 & $3.96 \pm 0.274$ & $20.76 \pm 8.163$ & $124.59 \pm 22.298$ & $0.28 \pm 0.002$ & $5.51 \pm 0.232$ & $15.71 \pm 1.382$ \\
\hline $120 / 120 / 14$ & 10 & $3.85 \pm 0.173$ & $18.02 \pm 6.984$ & $151.82 \pm 17.367$ & $0.20 \pm 0.029$ & $5.15 \pm 0.084$ & $19.22 \pm 1.776$ \\
\hline $120 / 180 / 14$ & 10 & $4.12 \pm 0.227$ & $12.05 \pm 3.325$ & $124.88 \pm 19.277$ & $0.18 \pm 0.033$ & $5.58 \pm 0.222$ & $19.77 \pm 2.758$ \\
\hline $135 / 150 / 16$ & 15 & $1.22 \pm 0.029$ & $64.89 \pm 22.438$ & $1044.84 \pm 44.042$ & $0.11 \pm 0.007$ & $3.29 \pm 0.194$ & $8.23 \pm 0.555$ \\
\hline $105 / 150 / 16$ & 15 & $3.26 \pm 0.122$ & $16.93 \pm 7.521$ & $196.95 \pm 15.273$ & $0.18 \pm 0.008$ & $4.81 \pm 0.043$ & $16.23 \pm 2.353$ \\
\hline $165 / 150 / 16$ & 15 & $1.78 \pm 0.518$ & $19.86 \pm 10.443$ & $476.54 \pm 255.512$ & $0.11 \pm 0.014$ & $5.39 \pm 0.032$ & $13.58 \pm 1.525$ \\
\hline $135 / 150 / 20$ & 15 & $2.96 \pm 0.116$ & $29.82 \pm 8.592$ & $257.99 \pm 18.863$ & $0.27 \pm 0.035$ & $5.57 \pm 0.276$ & $12.39 \pm 1.599$ \\
\hline $135 / 210 / 16$ & 15 & $3.57 \pm 0.262$ & $17.29 \pm 6.644$ & $170.13 \pm 29.056$ & $0.23 \pm 0.026$ & $5.57 \pm 0.392$ & $17.30 \pm 2.077$ \\
\hline $135 / 90 / 16$ & 15 & $2.94 \pm 0.188$ & $33.47 \pm 14.087$ & $240.97 \pm 39.647$ & $0.23 \pm 0.010$ & $4.56 \pm 0.053$ & $19.53 \pm 0.809$ \\
\hline $135 / 150 / 16$ & 15 & $3.57 \pm 0.160$ & $19.99 \pm 5.910$ & $167.84 \pm 21.262$ & $0.34 \pm 0.020$ & $5.10 \pm 0.090$ & $16.42 \pm 0.259$ \\
\hline $135 / 150 / 16$ & 15 & $3.63 \pm 0.295$ & $19.60 \pm 7.800$ & $157.22 \pm 33.467$ & $0.25 \pm 0.048$ & $5.27 \pm 0.071$ & $17.59 \pm 0.689$ \\
\hline $135 / 150 / 12$ & 15 & $1.23 \pm 0.032$ & $60.54 \pm 19.743$ & $1039.29 \pm 28.216$ & $0.15 \pm 0.027$ & $3.38 \pm 0.079$ & $10.57 \pm 0.835$ \\
\hline $150 / 120 / 14$ & 20 & $1.49 \pm 0.073$ & $38.90 \pm 16.620$ & $667.89 \pm 65.740$ & $0.14 \pm 0.007$ & $4.17 \pm 0.064$ & $12.73 \pm 0.161$ \\
\hline $120 / 180 / 18$ & 20 & $3.19 \pm 0.259$ & $19.43 \pm 10.542$ & $202.74 \pm 41.501$ & $0.23 \pm 0.019$ & $4.92 \pm 0.237$ & $22.62 \pm 1.528$ \\
\hline $150 / 180 / 14$ & 20 & $1.15 \pm 0.026$ & $33.52 \pm 12.613$ & $892.61 \pm 35.893$ & $0.22 \pm 0.015$ & $3.48 \pm 0.090$ & $9.58 \pm 0.735$ \\
\hline $120 / 180 / 14$ & 20 & $1.24 \pm 0.022$ & $55.02 \pm 20.530$ & $1049.98 \pm 26.036$ & $0.14 \pm 0.019$ & $3.07 \pm 0.030$ & $8.54 \pm 0.545$ \\
\hline $120 / 120 / 18$ & 20 & $2.92 \pm 0.203$ & $28.51 \pm 15.218$ & $276.00 \pm 51.918$ & $0.33 \pm 0.006$ & $4.74 \pm 0.055$ & $16.40 \pm 0.174$ \\
\hline $150 / 120 / 18$ & 20 & $2.05 \pm 0.349$ & $25.74 \pm 9.387$ & $401.91 \pm 95.653$ & $0.18 \pm 0.008$ & $4.88 \pm 0.019$ & $14.14 \pm 1.652$ \\
\hline $150 / 180 / 18$ & 20 & $1.82 \pm 0.385$ & $19.39 \pm 8.296$ & $479.94 \pm 198.248$ & $0.15 \pm 0.014$ & $5.42 \pm 0.373$ & $11.28 \pm 3.527$ \\
\hline $120 / 120 / 14$ & 20 & $1.25 \pm 0.019$ & $71.34 \pm 21.905$ & $1090.95 \pm 35.787$ & $0.18 \pm 0.042$ & $3.22 \pm 0.016$ & $10.74 \pm 1.006$ \\
\hline $135 / 150 / 16$ & 25 & $1.17 \pm 0.015$ & 44.7614 .982 & $1046.64 \pm 35.540$ & $0.13 \pm 0.045$ & $3.11 \pm 0.052$ & $10.78 \pm 1.273$ \\
\hline
\end{tabular}

$\mathrm{T}=$ Temperature $\left({ }^{\circ} \mathrm{C}\right) ; \mathrm{rpm}=$ screw speed $(\mathrm{rpm}) ; \mathrm{EM}=$ extrusion moisture $(\%) ;{ }^{*} \mathrm{SD}$ of the mean.

$(p<0.05)$ at low CSM concentrations occurs as a result of higher starch content in these products (greater expansion, less density).

\subsection{Water Activity (WA)}

WA determines shelf life of a product on the basis of chemical, biochemical, microbiological and physical changes [64]. Table 3 shows WA regression analysis. Temperature, screw speed, moisture content, and CSM concentration have an effect $(p<0.05)$ on extrudate WA. An increase on extrusion temperature, screw speed or CSM concentration results in a decrease $(p<0.05)$ on WA of extrudates. Extrusion at higher moisture content also increases $(p<0.05)$ extrudate WA unless extrusion moisture and temperature are increased simultaneously. High temperature and screw speed, which increase degradation of mechanical energy into thermal energy, increase water evaporation and reduce WA. According to the results, CSM restricts water availability. A similar effect has been observed in soy protein and soluble protein $[65,66]$. WA is below 0.4 in all extrudates (Table 4), which represents a microbiologically stable product [64]. WA for aquaculture extruded feed is between 0.58 and 0.44 [67]. The lower WA finding confirms that CSM decreases WA in the product due to high protein content, as explained above. 


\subsection{Water Absorption Index (WAI) and Water Solubility Index (WSI)}

Water absorption index (WAI) was not affected $(p>0.05)$ either by temperature or screw speed (Table 3). This finding is consistent with other researches [17]. WAI was affected $(p<0.05)$ by moisture and CSM content. High CSM concentrations decreased WAI. The resulting values are consistent with other findings where bean protein shows a negative effect on WAI [53], although these same authors report an increase in WAI by adding high protein bean fractions to extrudates. Other authors report no effect of bean protein on WAI [17]. These contradicting results are due to differences between bean protein and CSM protein. Other authors $[46,68,69]$, also found that moisture had an effect $(p<0.05)$ on WAI for just bean flour. WAI is between 3.0 and 6.0 (Table 4). Values in this study are higher than those reported by other authors $[17,70]$. High WAI indicates good water-holding capacity $[62,60]$. WAI is first and foremost linked to the amount of water absorbed by starch granules after swallow in water excess, and it can be used as a gelatinization grade index [70-72]. Second, WAI is related to the mixture's protein hydrophilic balance which changes according to the denaturalization grade of the aforementioned, where the extrusion process changes solubility profiles [73]. Increasing moisture content results in higher WAI due to an increase in water availability for starch granules [60]. In addition, amylose and amylopectin chains form at high temperature an expandable matrix that translates into a higher water retention capacity $[60,61]$. A high fiber and protein content in CSM creates a more compact structure, thus restricting water retention capacity within the matrix [61].

Water solubility index (WSI) decreased $(p<0.05)$ with increasing extrusion temperature and CSM content (Table 3), yet it increased $(p<0.05)$ when either screw speed and moisture content or moisture and CSM content increased simultaneously. WSI is directly related to levels of starch degradation occurring inside the extruder [18]. Results indicate that starch depolymerization did not take place at high temperatures in keeping with previous results [17]. This because, at high temperatures, protein denaturalization contributes to exposing hydrophobic groups located within the protein structure, which in turn results in solubility reduction [74-76]. High protein extrudates have a lower WSI than corn extrudates $[46,53,68]$. CSM proteins can interact with starch through crossed bonds formation [77,78], thus reducing product solubility. WSI values ranged from 8.23 to 19.77 , and are consistent with those reported by other authors $[17,72]$. Other authors found that high protein extrudates have a lower WSI than corn extrudates $[46,53,68]$.

\subsection{Mycotoxins}

Aflatoxins (B1, B2, G1 and G2 are the most common) are produced as metabolites by Aspergillus Flavus, and Aspergillus Parasiticus, which are found in nature all over the world. Aflatoxin B1 is the most toxic followed by G1. Toxicity for B2 and G2 is relatively weak [29]. Due to high toxicity and carcinogenicity to human and animals, the European Commission has set maximum levels for aflatoxin B1 at 2.0 to $8.0 \mu \mathrm{g} / \mathrm{kg}$ and for the total sum of all four aflatoxins (B1, B2, G1 and G2) at 4.0 to $15.0 \mu \mathrm{g} / \mathrm{kg}$ for crops such as nuts, grains and dried fruits [79]. The action level was set by US FDA at 20 to $300 \mu \mathrm{g} / \mathrm{kg}$ for human food and animal feed, respectively [80]. Table 2 shows the results of aflatoxins analyses, which indicate the safety of the product.

\subsection{Starch Analyses}

The results indicate that CSM/corn flour extrudates (Figure 1) have starch concentrations similar to taro, corn flour, bean/corn flour and corn extrudates [25,72]. EI increases as gelatinization in extrudates increases [81]. The extrusion conditions used showed good starch gelatinization (68.5\%), which explains the high EI obtained (Table 4). High gelatinization was reached because corn flour was pre-gelatinized during the nixtamal process and because the loss of crystalline order in the starch granule [26,81]. Although $30 \%$ of the starch is not gelatinized, 97.5\% of the starch is available after extrusion (Figure 1). This shows that while not all starch is gelatinized, changes in the native structure of the starch granules take place during extrusion and result in starch availability. With gelatinization and starch availability, speed and efficiency at which enzymes and microbes can break down starch bonds to release energy are increased, thus obtaining microbial protein from the irreversible destruction of

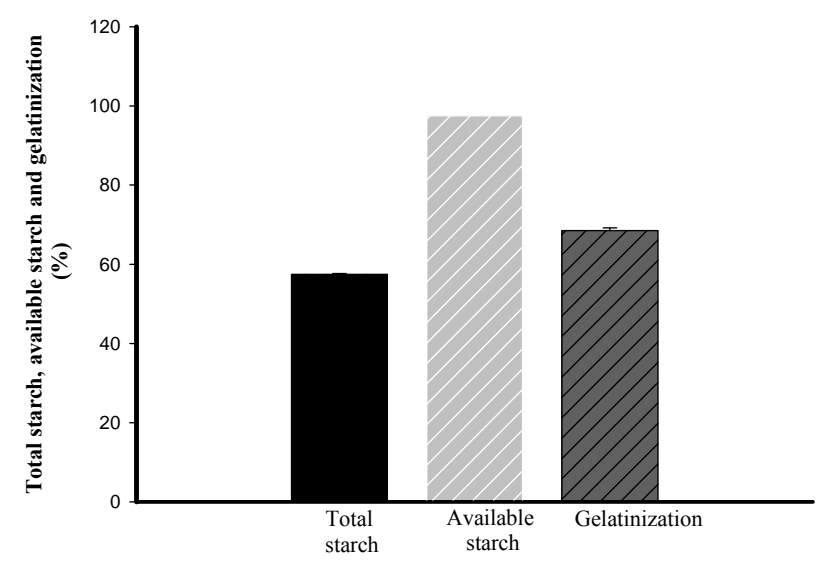

Figure 1. Total starch content, available starch and gelatinized starch of CSM/masa extruded snacks. $T$ indicate SD of the mean. 
the starch granules' crystalline order and making the surface of every molecule accessible to solvents or reactants [82].

\subsection{Optimization}

Numerical optimization was performed by superimposing different surface responses (establishing to maximize EI, WAI, and WSI; and minimize BD, PF and WA) for each one of the evaluated treatments. The optimal conditions were at a temperature of $120^{\circ} \mathrm{C}$, screw speed of 179.9 RPM, cottonseed meal content of $10.0 \%$ and moisture content of $16.8 \%$ with an EI of 4.36 , BD of 12.72 $\mathrm{Kg} / \mathrm{m}^{3}$, WAI of $5.88 \mathrm{~g} / \mathrm{g}$, WSI of $18.89 \%$, PF of $10.59 \mathrm{~N}$ and a WAI of 0.23 .

\section{Conclusion}

Extruded snacks were prepared containing $10 \%$ of cotton seed meal. They are nutritionally superior than commercial snacks, with $88 \%$ more protein content and less fat content. No mycotoxins were detected in the main ingredients. Availability of starch was high (97.5\%). Mixing CSM and corn flour can significantly $(p<0.05)$ increase dietary protein and lower fat content. Glandless cottonseed meal, an agro-industrial byproduct was used to develop an affordable snack. CSM extrudates are unique in that their protein matrix allows for a harder and crunchier product with lower water activity compared to other extruded snacks. Nevertheless, low levels of non-fiber carbohydrate in cotton seed meal limit the amount of CSM that can be used for extrudate production. Optimal conditions for extrusion were: temperature of $120^{\circ} \mathrm{C}$, screw speed of 179.9 rpm, cottonseed meal content of $10 \%$ and moisture content of $16.8 \%$. Glandless cottonseed meal can be a viable option for human and animal consumption. This not only in terms of nutritional value, but also in terms of extrudate production costs, since it possible to use both low temperatures and moisture contents. This research was conducted in close cooperation with the private sector in order to develop a product with a direct industrial application and commercial value.

\section{REFERENCES}

[1] C. M. Cater, K. F. Mattil, W. W. Meinke, M. V. Taranto, and J. T. Lawhon, "Cottonseed Protein Food Products," Journal of the American Oil Chemists' Society, Vol. 54, No. 2, 1977, pp. A90-A93.

[2] L. C. Beradi and L. A. Goldblatt, "Toxic Constituents of Plant Foodstuffs," 2nd Edition, Academic Press, New York, 1980, pp. 183-188.

[3] G. Francis, H. P. S. Makkar, and K. Becker, "Anti-Nutritional Factors Present in Plant-Derived Alternate Fish Feed Ingredients and Their Effects in Fish," Aquaculture,
Vol. 199, No. 3-4, 2001, pp. 197-199.

doi:10.1016/S0044-8486(01)00526-9

[4] P. H. Robinson, G. Getachew, E. J. DePeters and M. C. Calhoun, "Influence of Variety and Storage for Up to 22 Days on Nutrient Composition and Gossypol Level of Pima Cottonseed (Gossypium spp)," Animal Feed Science And Technology, Vol. 91, No. 3, 2001, pp. 149-154. doi:10.1016/S0377-8401(01)00202-4

[5] J. E. P. Santos, M. Villasenor, P. H. Robinson, E. J. DePeters and C. A. Holmberg, "Type of Cottonseed and Level of Gossypol in Diets of Lactating Dairy Cows: Plasma Gossypol, Health and Reproductive Performance," Journal of Dairy Science, Vol. 85, No. 6, 2005, pp. 14911501. doi:10.3168/jds.S0022-0302(02)74218-5

[6] M. V. Taranto, W. W. Meinke, C. M. Carter and K. F. Mattil, "Parameters Affecting Production and Character of Extrusion Texturized Defatted Glandless Cottonseed Meal," Journal of Food Science, Vol. 40, No. 6, 1975, pp. 1264-1269. doi:10.1111/j.1365-2621.1975.tb01068.x

[7] S. O. Serna-Saldivar, A. Tellez-Giron and L. W. Rooney, "Production of Tortilla Chips from Sorghum and Maize," Journal of Cereal Science, Vol. 8, No. 3, 1998, pp. 275284. doi:10.1016/S0733-5210(88)80039-0

[8] O. Paredes-Lopez and M. E. Sarharopulos, "Scanning Electron Microscopy of Limed Corn Kernels for Tortilla Marking," Journal of Food Technology, Vol. 17, No. 6, 1982, pp. 687-693.

doi:10.1111/j.1365-2621.1982.tb00228.x

[9] J. K. Gomez, C. M. McDonough, L. W. Rooney and R. D. Waniska, "Corn Starch Changes during Tortilla and Tortilla Chip Processing," Cereal Chemistry, Vol. 69, No. 3, 1989, pp. 275-279.

[10] M. H. Gomez, J. K. Lee, C. M. McDonough, R. D. Waniska and L. D. Rooney, "Corn Starch Changes during Tortilla and Chip Processing," Cereal Chemistry, Vol. 69, No. 3, 1991, pp. 275-279.

[11] M. H. Gomez, R. D. Waniska and L. W. Rooney, "Effects of Nixtamalization and Grinding Conditions on Starch in Corn Flour," Starch/Starke, Vol. 42, No. 12, 1990, pp. 475-482. doi:10.1002/star.19900421207

[12] R. L. Pflugfelder, L. W. Rooney and R. D. Waniska, "Fractionation and Composition of Commercial Corn Corn Flour," Cereal Chemistry, Vol. 65, 1988, pp. 262266.

[13] A. Trejo-Gonzalez, A. Feria-Morales and C. Wild-Altamirano, "The Role of Lime in the Alkaline Treatment of Corn for Tortilla Preparation," Advances in Chemistry Series, Vol. 198, 1982, pp. 245-263.

[14] M. E. Rodriguez, J. M. Yáñez-Lomón, J. J. Alvarado, H. Vargas, F. Sánchez-Sinencio, F. Figueroa, B. F. Martínez, J. Gonzalez-Hernandez, M. D. Silva and L. C. Miranda, "Influence of the Structural Changes during Alkaline Cooking on the Thermal, Rheological, and Dielectric Properties of Maite Tortillas," Cereal Chemistry, Vol. 73, 1996, pp. 593-600.

[15] C. M. Bryant and B. R. Hamaker, "Effect of Lime on Gelatinization of Corn Flours and Starch," Cereal Chemistry, Vol. 74, No. 2, 1997, pp. 171-175. 
doi:10.1094/CCHEM.1997.74.2.171

[16] J. L. Fernández-Muñoz, M. E. Rodríguez, R. C. Pless, H. E. Martínez-Flores, M. Leal, J. L. Martínez and L. Baños, "Changes in Nixtamalized Corn Flour Dependen Ton Post Cooking Sleeping Time," Cereal Chemistry, Vol. 79, No. 1, 2002, pp. 162-166. doi:10.1094/CCHEM.2002.79.1.162

[17] M., Atienzo-Lazos, E. Delgado, A. Ochoa-Martínez, E. Aguilar-Palazuelos, B. F. Martínez, B. Ramirez-Wong, A. Gallegos-Infante, H. Medrano-Roldan and A. Solis-Soto, "Effect of Moisture and Temperature on the Functional Properties of Composite Flour Extrudates from Beans (Phaseolus vulgaris) and Nixtamalized Corn (Zea mays)," Journal of Animal Production Advances, Vol. 1, No. 1, 2012, pp. 9-20.

[18] J. M. Harper, "Extrusion of Foods," CRC Press, Inc., Boca Raton, 1981.

[19] S. S. Wang, W. C. Chiang, A. I. Yeh, B. Zhao and I. H. Kim, "Kinetics of Phase Transition of Waxy Corn Starch at Extrusion Temperature and Moisture Contents," Journal Food Science, Vol. 54, No. 5, 1989, pp. 1298-1301. doi:10.1111/j.1365-2621.1989.tb05977.x

[20] C. G. Biliaderis, T. J. Maurice and J. R. Vose, "Starch Gelatinization Phenomena Studies by Different Scanning Calorimetry," Journal of Food Science, Vol. 45, No. 6, 1980, pp. 1669-1674. doi:10.1111/j.1365-2621.1980.tb07586.x

[21] D. V. Zasypkin and L. Tung-Ching, "Extrusion of Soybean and Wheat Flour as Affected by Moisture Content," Journal of Food Science, Vol. 63, No. 6, 1998, pp. 10581061. doi:10.1111/j.1365-2621.1998.tb15854.x

[22] N. Wang, P. R. Bhlrud, F. W. Sosulski and R. T. Tyler, "Pasta-Like Products from Pea Flour by Twin-Screw Extrusion," Journal of Food Science, Vol. 64, No. 4, 1999, pp. 671-678. doi:10.1111/j.1365-2621.1999.tb15108.x

[23] D. Reyes-Jáquez, J. Vargas-Rodríguez, E. Delgado, J. Rodríguez-Miranda, E. E. Araiza-Rosales, I. Andrade-González, A. Solís-Soto and H. Medrano-Roldan, "Optimization of the Extrusion Process Temperature and Moisture Content on the Functional Properties and in Vitro Digestibility of a Bovine Cattle Feed Made out of Waste Bean Flour," Journal of Animal Science Advances, Vol. 1, No. 2, 2011, pp. 100-110.

[24] E. Delgado, M. I. Vences-Montaño, N. E. Rocha-Guzman, A. Rodriguez-Vidal, S. M. Herrera-Gonzalez, H. Medrano-Roldan and A. Solis-Soto, "Inhibition of the Growth of Rats by Extruded Snacks from Bean (Phaseolus vulgaris) and Corn (Zea mays)," Emirates Journal Food and Agriculture, Vol. 24, No. 3, 2012, pp. 255-263.

[25] J. Rodríguez-Miranda, E. Delgado, B. Ramírez-Wong, A. Solís-Soto, M. A. Vivar-Vera, C. A. Gómez-Aldapa and H. Medrano-Roldán, "Effect of Moisture, Extrusion Temperature and Screw Speed on Residence Time, Specific Mechanical Energy and Psychochemical Properties of Bean Four and Soy Protein Aquaculture Feeds," Journal of Animal Production Advances, Vol. 2, No. 1, 2012, pp. 65-73.

[26] J. Rodríguez-Miranda, I. I. Ruiz-López, E. Herman-Lara,
C. E. Martínez-Sánchez, E. Delgado-Licón and M. A. Vivar Vera, "Development of Extruded Snacks Using Taro (Colocasia esculenta) and Nixtamalized Maize (Zea mays) Flour Blends," Food Science and Technology, Vol. 44, No. 3, 2011, pp. 673-680. doi:10.1016/j.lwt.2010.06.036

[27] Association of Official Analytical Chemistry (AOAC), "International, Official Methods of Analysis," 15th Edition, The Association of Official Analytical Chemists, Arlington, 2005.

[28] E. Solanas, C. Castrillo and S. Calsamiglia, "Effect of Extruding the Cereal and/or the Legume Protein Supplement of a Compound Feed on in Vitro Ruminal Nutrient Digestion and Nitrogen Metabolism," Journal of Animal Physiology and Animal Nutrition, Vol. 91, No. 5-6, 2007, pp. 269-277. doi:10.1111/j.1439-0396.2007.00704.x

[29] X. L. Yang and R. An, "Determinations of Aflatoxins (B1, B2, G1 and G2) in Corn and Peanut Butter by HPLCFLD Using Pre-Column Immunoaffinity Cleanup and Post-Column Electrochemical Derivatization," Life Science and Chemical Analysis Group, Agilent Technologies, Shanghai, 2011.

[30] E. Gujska and K. Khan, "Effect of Temperature on Properties of Extrudates from High Starch Fractions of Navy, Pinto and Garbanzo Beans," Journal of Food Science, Vol. 55, No. 2, 1990, pp. 466-469.

[31] W. M. Wang, C. F. Klopfenstein and J. G. Ponte, "Effects of Twin-Screw Extrusion on the Physical Properties of Dietary Fiber and Other Components of Whole Wheat and Wheat Bran and on the Baking Quality of the Wheat Bran," Cereal Chemistry, Vol. 70, No. 6, 1993, pp. 707711.

[32] R. A. Anderson, H. F. Conway, V. F. Pfeifer and E. L. Griffin, "Gelatinization of Corn Grits by Roll and Extrusion Cooking," Cereal Science Today, Vol. 14, No. 1, 1969, pp. 4-12.

[33] G. Contreras, L. G. Elias and R. Bressani, "Limitations of Corn (Zea mays) and Common Bean (Phaseolus vulgaris) Diets as Protein and Calorie Sources," Vol. 30, No. 2, 1980, pp. 145-153.

[34] M. R. Molina, J. E. Braham and R. Bressani, "Some Characteristics of Whole Corn: Whole Soybean (70:30) and Rice: Whole Soybean (70:30) Mixtures Processed by Simple Extrusion Cooking," Journal of Food Science, Vol. 48, No. 2, 1983, pp. 434-437. doi:10.1111/j.1365-2621.1983.tb10759.x

[35] N. K. Rao and M. Shahid, "Potential of Cowpea [Vigna unguiculata (L.) Walp.] and Guar [Cyamopsis tetragonoloba (L.) Taub.] as Alternative Forage Legumes for the United Arab Emirates," Emirates Journal of Food Agriculture, Vol. 23, No. 2, 2011, pp. 147-156.

[36] I. A. Akinyele, "Fermentation Studies on Maize during the Preparation of Traditional African Starch-Cake Food," Journal of Food Science and Agriculture, Vol. 21, 1970, pp. 619-25. doi:10.1002/jsfa.2740211205

[37] R. Bressani, J. E. Braham, L. G. Elias and M. Rubio, "Further Studies on the Enrichment of Lime Treated Corn with Whole Soybeans," Journal of Food Science, Vol. 44, 
No. 6, 1979, pp. 1707-1710.

doi:10.1111/j.1365-2621.1979.tb09121.x

[38] S. Dhingra and S. Jood, "Organoleptic and Nutrition Evaluation of Wheat a Breads Supplemented with Soybean and Barley Flour," Food Chemistry, Vol. 77, No. 4, 2007, pp. 479-488. doi:10.1016/S0308-8146(01)00387-9

[39] E. O. Giwa and V. Ikujenlola Abiodun, "Quality Characteristics of Biscuits Produced from Composite Flours of Wheat and Quality Protein Maize," African Journal of Food Science and Technology, Vol. 1, No. 5, 2010, pp. 116-119.

[40] J. Cabrera, L. E. Zapata, T. S. de Buckle, I. Ben-Gera, A. M. de Sandoval and I. Shomer, "Production of Textured Vegetable Protein from Cottonseed Flours," Journal of Food Science, Vol. 44, No. 3, 1979, pp. 826-830. doi:10.1111/j.1365-2621.1979.tb08512.x

[41] D. V. Zasypkin and L. Tung-Ching, "Extrusion of Soybean and Wheat Flour as Affected by Moisture Content," Journal of Food Science, Vol. 63, No. 6, 1998, pp. 10581061. doi:10.1111/j.1365-2621.1998.tb15854.x

[42] J. Owusu-Ansah, F. R. van de Voort and D. W. Stanley, "Textural and Microstructural Changes in Corn Starch as a Function of Extrusion Variables," Canadian Institute of Food Science and Technology Journal, Vol. 17, No. 2, 1984, pp. 65-70.

[43] H. J. H. De Muelenaere and J. L. Buzzard, "Cooker Extruders in Service of World Feeding," Food Technology, Vol. 23, No. 3, 1969, pp. 345-348.

[44] J. M. Harper, "Extrusion of Foods," CRC Press, Boca Raton, 1981.

[45] M. V. Taranto, W. W. Meinke, C. M. Carter and K. F. Mattil, "Parameters Affecting Production and Character of Extrusion Texturized Defatted Glandless Cottonseed Meal," Journal of Food Science, Vol. 40, No. 6, 1975, pp. 1264-1269. doi:10.1111/j.1365-2621.1975.tb01068.x

[46] R. R. Balandran-Quintana, G. V. Barbosa-Canovas, J. J. Zazueta-Morales, A. Anzaldua-Morales and A. QuinteroRamos, "Functional and Nutritional Properties of Extruded Whole Pinto Bean Meal (Phaseolus vulgaris L.)," Journal of Food Science, Vol. 63, No. 1, 1998, pp. 113116. doi:10.1111/j.1365-2621.1998.tb15688.x

[47] B. Y. Chiang and J. A. Johnson, "Measurement of Total and Gelatinized Starch by Glucoamylase and O-Toluidine Reagent," Cereal Chemistry, Vol. 54, No. 3, 1977, pp. 429-435.

[48] R. Chinnaswamy and M. A. Hanna, "Optimum Extrusion Cooking Conditions for Maximum Expansion of Corn Starch," Journal of Food Science, Vol. 53, No. 3, 1987, pp. 834-836. doi:10.1111/j.1365-2621.1988.tb08965.x

[49] P. Colonna, J. L. Doublier, J. P. Melcion, F. De Monredon and C. Mercier, "Extrusion Cooking and Drum Drying of Wheat Starch. Physical and Macromolecular Modifications," Cereal Chemistry, Vol. 61, No. 6, 1984, pp. 538-543.

[50] V. J. Davidson, D. Paton, L. L. Diosady and G. Larocque, "Degradation of Wheat Starch in a Single-Screw Extruder: Characteristics of Extruded Starch Starch Polymers,"
Journal of Food Science, Vol. 49, No. 2, 1984, pp. 453458.

[51] G. Sacchetti, P. Pittiam and G. G. Pinnavaia, "The Effect of Extrusion Temperature and Drying-Tempering on Both of Kinetics of Hydration and the Textural Changes in Extruded Ready-to-Eat Breakfast Cereals during Soaking in Semi-Skimmed Milk," International Journal of Food Science and Technology, Vol. 40, No. 6, 2005, pp. 655-663. doi:10.1111/j.1365-2621.2005.00976.x

[52] M. V. Tarantano, G. F. Cegla, K. R. Bell and K. C. Rhee, "Textured Cottonseed and Soy Flours: A Microscopic Analysis," Journal of Food Science, Vol. 43, No. 3, 1978, pp. 767-771. doi:10.1111/j.1365-2621.1978.tb02414.x

[53] E. Y. Gujska and K. Khan, "Functional Properties of Extrudates from High Starch Fractions of Navy and Pinto Beans and Corn Meal Blended with Legume High Protein Fractions," Journal of Food Science, Vol. 56, No. 2, 1991, pp. 431-435. doi:10.1111/j.1365-2621.1991.tb05297.x

[54] T. S. de Buckle, L. E. Zapata, G. Silva, J. Cabrera, A. M. de Sandoval, I. Ben-Gera, H. Riveros and I. Shomer, "Two Food Applications of Cottonseed Flours and Meals," Journal of American Oil Chemists' Society, Vol. 56, No. 3, 1979, pp. 297-299.

[55] M. E. Camire, "Chemical and Nutritional Changes in Food during Extrusion," Food Science Nutrition, Vol. 29, No. 1, 1990, pp. 35-57. doi:10.1080/10408399009527513

[56] J. Zazueta-Morales, F. Martínez-Bustos, N. JacoboValenzuela, C. Ordorica-Falomir and O. Paredes-López, "Effects of Calcium Hydroxide and Screw Speed on Physicochemical Characteristics of Extruded Blue Maize," Journal of Food Sciences, Vol. 67, No. 9, 2002, pp. 33503357. doi:10.1111/j.1365-2621.2002.tb09590.x

[57] C. Pérez-Navarrete, R. Gonzáles, L. Chel-Guerrero and D. Betancur-Ancona, "Effect of Extrusion on Nutritional Quality of Maize and Lima Bean Flour Blends," Journal World Aquaculture Society, No. 86, No. 14, 2006, pp. 2477-2484.

[58] D. V. Zasypkin and L. Tung-Ching, "Extrusion of Soybean and Wheat Flour as Affected by Moisture Content," Journal of Food Science, Vol. 63, No. 6, 1998, pp. 10581061. doi:10.1111/j.1365-2621.1998.tb15854.x

[59] T. De Pilli, B. F. Carbone, A. Derossi, A. G. Fiore and C. Severini, "Effects of Operating Conditions on Oil Loss and Structure of Almond Snacks," Journal of Food Science, Vol. 43, No. 3, 2008, pp. 430-439.

[60] P. Colonna, J. Tayeb and C. Mercier, "Extrusion Cooking of Starch and Starchy Products, in Extrusion Cooking," American Association of Cereal Chemists, Inc., St. Paul, 1989, pp. 247-319

[61] D. Karuna, D. Noel and K. Dilip, "Food and Nutrition Bulleting," United Nation University, Vol. 17, No 2, 1996.

[62] J. L. Kokini, I. Lai and L. L. Chedid, "Effect of Starch Structure on Starch Rheological Properties," Food technology, Vol. 46, No. 6, 1992, pp. 124-139.

[63] J. M. Faubion and R. C. Hoseney, "High-Temperature Short Time Extrusion Cooking of Wheat Starch and Flour. 
II. Effect of Protein and Lipid on Extrudate Properties," Cereal Chemistry, Vol. 59, No. 6, 1982, pp. 529-533.

[64] O. R. Fennema, "Food Chemistry," 2nd Edition, Marcell Dekker, Inc., New York, 1985, pp. 46-50.

[65] B. Vallejo-Cordoba, S. Nakai, W. D. Powrie and T. Beveridge, "Protein Hydrolysates for Reducing Water Activity in Meat Products," Journal of Food Science, Vol. 51, No. 5, 1986, pp. 1156-1161. doi:10.1111/j.1365-2621.1986.tb13072.x

[66] A. Shibata, Y. Iizuka, S. Ueno and T. Yamashita, "Effect of Water Activity on Unfolding of Adsorbed Protein at the Interface," The Solid Films, Vol. 284-285, 1996, pp. 549-551.

[67] N. Chevanan, K. Muthukumarappan and K. A. Rosentrater, "Extrusion Studies of Aquaculture Feed using Distillers Dried Grains with Solubles and Whey," Food Bioprocess Technology, Vol. 2, No. 2, 2009, pp. 177-185. doi:10.1007/s11947-007-0036-8

[68] R. A. Anderson, "Water Absorption and Solubility and Amylograph Characteristics on Roll-Cooked Small Grain Products," Cereal Chemistry, Vol. 59, No. 4, 1982, pp. 265-269.

[69] R. A. Anderson, H. F. Conway and Y. F. Pfeiser, "Gelatinization of Corn Grits by Roll-and Extrusion Cooking," Cereal Chemistry, Vol. 59, 1969, pp. 265-269.

[70] R. M. Van den Einde, A. J. Van der Goot and R. M. Boom, "Understanding Molecular Weight Reduction of Starch during Heating-Shearing Process," Journal of Food Science, Vol. 68, 2003, pp. 396-400.

[71] N. Chevanan, K. A. Rosentrater and K. Muthukumarappan, "Twin Screw Extrusion Processing of Feed Blends Containing Distiller's Dried Grains with Solubles (DDGS)," Cereal Chemistry, Vol. 84, No. 5, 2007, pp. 428436. doi:10.1094/CCHEM-84-5-0428

[72] J. Rodríguez-Miranda, I. I. Ruiz-López, E. Herman-Lara, C. E. Martínez-Sánchez, E. Delgado-Licon and M. A. Vivar-Vera, "Development of Extruded Snacks Using Taro (Colocasia esculenta) and Nixtamalized Maize (Zea mays) Flour Blends," Food Science and Technology, Vol. 44, No. 3, 2011, pp. 673-680. doi:10.1016/j.lwt.2010.06.036

[73] S. Singh, S. Gamlath and L. Wakeling, "Nutritional Aspects of Food Extrusion: A Review," International Journal of Food Science and Technology, Vol. 42, No. 8,
2007, pp. 916-929.

doi:10.1111/j.1365-2621.2006.01309.x

[74] E. L. Arrese, D. A. Sorgentini, J. R. Wagner and M. C. Anon, "Electrophoretic, Solubility and Functional Properties of Commercial Soy Protein Isolates," Journal of Agriculture Food Chemistry, Vol. 39, No. 3, 1991, pp. 1029-1032. doi:10.1021/jf00006a004

[75] B. Nagmani and J. Prakash, "Functional Properties of Thermally Treated Legume Flours," International Journal of Food Science Nutrition, Vol. 48, No. 3, 1997, pp. 205-214. doi:10.3109/09637489709012594

[76] A. Ionescu, I. Aprodu, A. Darabă, G. Gurău, C. Baciu. and A. Nichita, "Chemical and Functional Characterization of Chickpea Protein Derivates," The Annals of the University Dunarea de Jos of Galati, Vol. 33, 2009, pp. 16-27.

[77] P. K. Goel, R. S. Singhal and P. R. Kulkarni, "Studies on Interactions of Corn Starch with Casein and Casein Hydrolysates," Food Chemistry, Vol. 64, No. 3, 1999, pp. 383-389. doi:10.1016/S0308-8146(98)00134-4

[78] J. A. Fernández-Gutiérrez, E. S. Martin-Martínez, F. Martínez-Bustos and A. Cruz-Orea, "Physicochemical Properties of Casein-Starch Interaction Obtained by Extrusion Process," Starch/Stärke, Vol. 56, No. 5, 2004, pp. 190198.

[79] Commission Regulation (EC), "No 1881/2006 of 19 December 2006 Setting Maximum Levels for Certain Contaminants in Foodstuffs," Official Journal of the European Union, Vol. 49, No. L364, 2006, pp. 5-24.

[80] US Food and Drug Administration, “Action Levels for Poisonous or Deleterious Substances in Human Food and Animal Feed, Industry Activities Staff Booklet," 2000. http://www.cfsan.fda.gov/ 1rd/fdaact.html

[81] M. Atienzo-Lazos, E. Delgado-Licon, A. Ochoa-Martínez, F. Martínez-Bustos, B. Ramírez-Wong, J. A. Gallegos-Infante, H. Medrano-Roldan, "Extrusion in Preparing Snack Foods," Artes Gráficas La Impresora, 2009.

[82] C. J. Sniffen, M. B. de Ordanza and R. Ward, "Interpreting and Implementing Starch Digestibility Information in the Field," Proceedings of the Cornell Nutrition Conference for Feed Manufacturers, Department of Animal Science of the New York College of Agriculture and Life Sciences, 2009. 